Гандзюк М.О., Гандзюк Д.М., Шумік Б.В.

Луиький національний технічний університет

\title{
РОЗРОБКА МЕТОДИКИ ОПЕРАТИВНОГО ПЛАНУВАННЯ РОБОТИ АВТОМОБІЛІВ НА МІЖМІСЬКИХ МАРШРУТАХ
}

\begin{abstract}
В даний час успішна робота всіх галузей народного господарства неможлива без ефективного транспортного обслуговування. Організація роботи транспорту повинна забезпечувати ефективне постачання промислового виробництва, сільського господарства, інших галузей народного господарства, а також задовольняти потреби населення в перевезеннях з системних позицій. Комплексний підхід до організації та планування перевезень вимагає досягнення мінімальних витрат як у всій системі транспортного обслуговування, так і в окремих іiі елементах. Вирішення цього завдання неможливо без заміщення існуючих раніше технологій і методів організації і планування транспортного процесу на сучасні.

Сучасні вимоги до організації перевізного процесу та якості виконуваних перевезень на автомобільному транспорті диктують необхідність застосування нових організаційних і технологічних рішень в плануванні перевезень з використанням програмно-цільових і логістичних принципів.

Існуюча організація системи оперативного планування не завжди відповідає реальним потребам учасників процесу вантажних автомобільних перевезень. Основним недоліком на сьогоднішній день $\epsilon$ те, що методологічна база сегментована і описує окремі етапи планування процесу перевезень. Методики, які працюють сьогодні, присвячені окремим завданням, таким як визначення оптимальної вантажопідйомності парку рухомого складу, розрахунок техніко експлуатаційних показників, в тому числі необхідної кількості автомобілів, розподіл рухомого складу за заявками із застосуванням методів лінійного програмування, складання графіка роботи автомобілів, розрахунок витрат на перевезення та інші.

Виконання такого різноманіття розрізнених операцій і завдань в сучасних умовах без комплексного підходу до їх вирішення, а також без автоматизації переробки значних обсягів інформації неефективне.

Крім того методики розрахунку необхідної кількості автомобілів мають серйозні похибки, це виражається в невідповідності розрахункових і фактичних величин.

Незважаючи на те, що останніми роками ведеться активна розробка і впровадження на автотранспортні підприємства програм автоматизованого документообігу та планування роботи автомобілів, в даний час не існує методики, яка забезпечує комплексне планування та рішення перерахованих вище завдань з урахуванням специфіки міжміських перевезень, тоді як сучасні тенденції розвитку автотранспорту в Україні пов'язані 3 інтенсивним їх розвитком.

Ключові слова: перевезення, техніко-експлуатаційні показники, міжміський маршрут, система, оперативне планування, заявка, методика, алгоритм, автоматизація, методологічна база.
\end{abstract}

\section{ВСТУП}

На сьогоднішній день існує безліч методик для оптимізації роботи рухомого складу i визначення ТЕП його роботи. Однак більшою частиною, вони можуть бути застосовані для здійснення планування і оцінки роботи автомобілів, зайнятих на міських маршрутах.

Систематизація сучасної методологічної бази розрахунку техніко-експлуатаційних показників для міжміських перевезень дозволяє стверджувати:

- методики які працюють сьогодні присвячені окремим завданням, таким як визначення оптимальної вантажопідйомності парку рухомого складу, розрахунок техніко-експлуатаційних показників, в тому числі необхідної кількості автомобілів, розподіл рухомого складу по заявках із застосуванням методів лінійного програмування, складання графіка роботи автомобілів, розрахунок витрат на перевезення та інші.

Виконання такого різноманіття розрізнених операцій і завдань в сучасних умовах без комплексного підходу до їх вирішення, а також без автоматизації переробки значних обсягів інформації неефективне;

- багато методик розрахунку техніко-експлуатаційних показників і, в тому числі, необхідної кількості автомобілів для виконання заданого обсягу перевезень базуються на фіксованому значенні вантажопідйомності автомобіля, в той час як визначення оптимальної вантажопідйомності має передувати визначенню необхідної кількості автомобілів. В цьому випадку, якщо диспетчер здійснює «вручну» підбір транспортних засобів різної вантажопідйомності на заявку, витрати часу i трудовитрати значні;

- більшість існуючих методик розроблені для планування міських перевезень з незначними витратами часу на оборот рухомого складу, що не застосовується в умовах міжміських перевезень; 
- в даний час в якості тимчасового інтервалу для планування роботи рухомого складу використовуються, за звичай, «доба» і «рік», але специфіка міжміських перевезень іноді вимагає використання інших тимчасових інтервалів;

- у разі використання наявних методик виникає похибка при розрахунку необхідної кількості автомобілів, що експлуатуються на міжміських маршрутах, за умови регламентації часу відправлення та доставки вантажу;

- для складання графіка роботи автомобілів на лінії службовцям, для уточнення і перевірки можливості виконання перевезень розрахованою кількістю автомобілів, застосовуються, за звичай, не автоматизовані трудомісткі графоаналітичні методи;

- розподіл автомобілів по заявках 3 урахуванням їх вантажопідйомності проводиться за допомогою методів лінійного програмування, проте використання критерію часу в рішенні транспортної задачі порушує лінійність завдання. Внесення інформації про наявність вільного рухомого складу при вирішенні транспортної задачі відбувається «вручну». До сьогодні процес розподілу рухомого складу по заявках 3 допомогою економіко-математичних методів не автоматизовано.

Для того щоб достовірно описати технологічний процес перевезень необхідно чітко уявляти собі часовий відрізок, протягом якого відбуваються події.

3 огляду на особливості умов роботи рухомого складу, експлуатованого на міжміських маршрутах, пропонується здійснювати планування техніко-експлуатаційних показників його роботи не за добу, а за більший період часу. Для розрахунку ТЕП може бути використаний рік, півріччя, сезон, квартал, місяць, тиждень або час виконання заявки з урахуванням повернення автомобіля в початковий пункт маршруту.

\section{АНАЛІЗ ЛІТЕРАТУРНИХ ДАНИХ ТА ПОСТАНОВКА ПРОБЛЕМИ}

В даний час актуальність інтенсивного розвитку автомобільних вантажних перевезень стала вагомою не тільки в ділових колах автотранспортної галузі, а й на державному рівні. Зокрема це відображено в Національній транспортній стратегії України до 2030 року, прийнятій розпорядженням Кабінету Міністрів України від 30 травня 2018 р. № 430-р.

Для задоволення зростаючого попиту на переміщення вантажів в міжміському і міжнародному сполученні виникає необхідність збільшення продуктивності роботи рухомого складу за рахунок якісного оновлення парку рухомого складу, раціонального використання наявного потенціалу провізних можливостей, оперативного планування роботи автомобілів на маршрутах.

Зниження якості надання транспортних послуг підприємствами автомобільного транспорту викликано рядом причин, які пов'язані як з технічними аспектами функціонування підприємств, так $\mathrm{i}$ 3 нераціональною організацією планування на підприємствах.

Існуюча організація системи оперативного планування не завжди відповідає реальним потребам учасників процесу вантажних автомобільних перевезень. Основним недоліком на сьогоднішній день $є$ те, що методологічна база сегментована і описує окремі етапи планування процесу перевезень. Методики, які працюють сьогодні, присвячені окремим завданням. Велика розмірність завдань і велика кількість суттєвих для практики обмежень призводить до неможливості отримання оптимальних рішень традиційними методами.

Проблеми оптимізації роботи рухомого складу і визначення ТЕП його роботи частково розглянуті у роботи вітчизняних і зарубіжних вчених, а саме Войтенкова С.С., Житкова В.А., Калініченка О.П., Кіма К.В., Крамаренка Ю.М., Менухової Т.А., Нефьодова В.М., Оліскевича М.С., Павленка О.В., Подоляка О.С., Прокудіна Г.С., Смрковскої В.Ю. та інших.

\section{ЦІЛЬ ТА ЗАДАЧІ ДОСЛІДЖЕННЯ}

Проведений аналіз сучасних підходів до вирішення задач оперативного планування вантажних перевезень на автомобільному транспорті дозволяє зробити висновок, що однією 3 перспективних задач підвищення якості оперативного планування є розробка методики оперативного планування роботи автомобілів на міжміських маршрутах, яка дозволяла б виконувати одночасно операції по визначенню раціональної вантажопідйомності автомобілів щодо вимог заявки, розраховувати необхідну кількість автомобілів з урахуванням оптимальної продуктивності рухомого складу і витрат на перевезення, обліковувати витрати на перевезення і розраховувати техніко-експлуатаційні показники роботи рухомого складу, визначати зайнятість парку автомобілів в будь-який момент часу. 


\section{РЕЗУЛЬТАТИ ДОСЛІДЖЕНЬ}

Для вдосконалення оперативного планування роботи автомобілів на міжміських маршрутах необхідно мати методику, яка адекватно відповідає сучасним умовам функціонування і потребам учасників ринку транспортних послуг.

При цьому слід керуватися принципом системного комплексного підходу, суть якого полягає не у встановленні відповідності того чи іншого параметра чинним нормам і вимогам, а в знаходженні рішення, що дозволяє не тільки формально усунути зазначений недолік, але і знайти варіант поліпшення цього показника, підвищити ефективність використання кожного елемента наявного технологічного потенціалу, досягти найкращого результату. У зв'язку з чим потрібно не тільки вивчати існуючий стан об'єкта дослідження, а й розглядати перспективи його розвитку.

Для оцінки діяльності автотранспортного підприємства застосовується системний комплексний підхід. Автотранспортне підприємство може бути розглянуто як єдина система забезпечення потреби клієнтів в перевезеннях.

Автотранспортне підприємство можна розглядати як систему з підсистемами, в якості яких виступають структурні підрозділи підприємства, від діяльності яких безпосередньо залежить робота підприємства в цілому. Використовуючи системний аналіз для формування структури управління процесом перевезення, можна виділити основні функціональні елементи системи. Для автотранспортного підприємства це структурні підрозділи (відділи), що знаходяться в постійному взаємозв'язку.

При дослідженні всієї системи відділів автотранспортного підприємства 3 їх завданнями, функціями і обов'язками ці підрозділи не можна розглядати окремо один від одного, оскільки досягнення мети - забезпечення виконання замовлень в повному обсязі і в строк при мінімальних витратах - можливо лише при системному комплексному підході.

Автотранспортне підприємство можна розглядати як систему управління перевезеннями. Для вдосконалення процесів перевезень широко використовується PDCA-підхід (Plan-Do-Check-Act (Плануй - Роби - Перевіряй - Дій), який використовується при впровадженні змін і вирішенні проблем (рисунок 1).

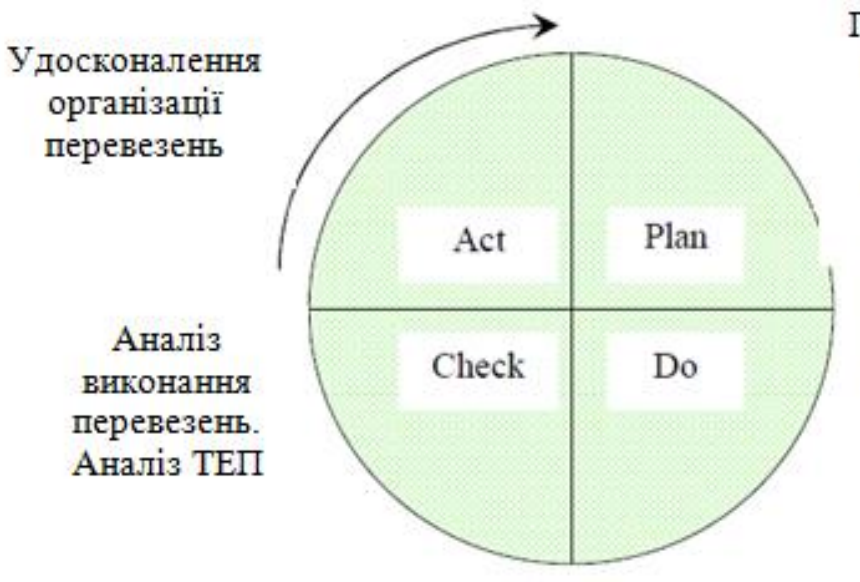

\section{Планування перевезень. \\ Визначення перевізної можливості РC. \\ Розподіл РС. \\ Розрахунок планових TEח}

\section{Виконання заявки - \\ здійснення перевезення у \\ визначеному об' $\mathrm{emi} \mathrm{в}$ \\ визначений термін}

Рисунок 1 - РDCA-підхід при плануванні, аналізі та вдосконаленні діяльності автотранспортного підприємства

У цій системі велике значення мають етапи планування та аналізу діяльності підприємства. В якості зворотнього зв'язку для визначення ефективності функціонування автотранспортного підприємства, як даної системи, використовуються техніко-експлуатаційні показники (ТЕП) роботи рухомого складу.

Визначення необхідної кількості автомобілів на автотранспортному підприємстві повинно здійснюватися з урахуванням максимальної ефективності.

Забезпечення виконання замовлень в повному обсязі і в строк при мінімальних витратах може бути досягнуто створенням оптимальних перевізних можливостей автотранспортного підприємства i підвищенням їх ефективності.

Схема перетворення потреби клієнтів в задоволеність при проходженні через систему автотранспортного підприємства представлена на рисунку 2. 


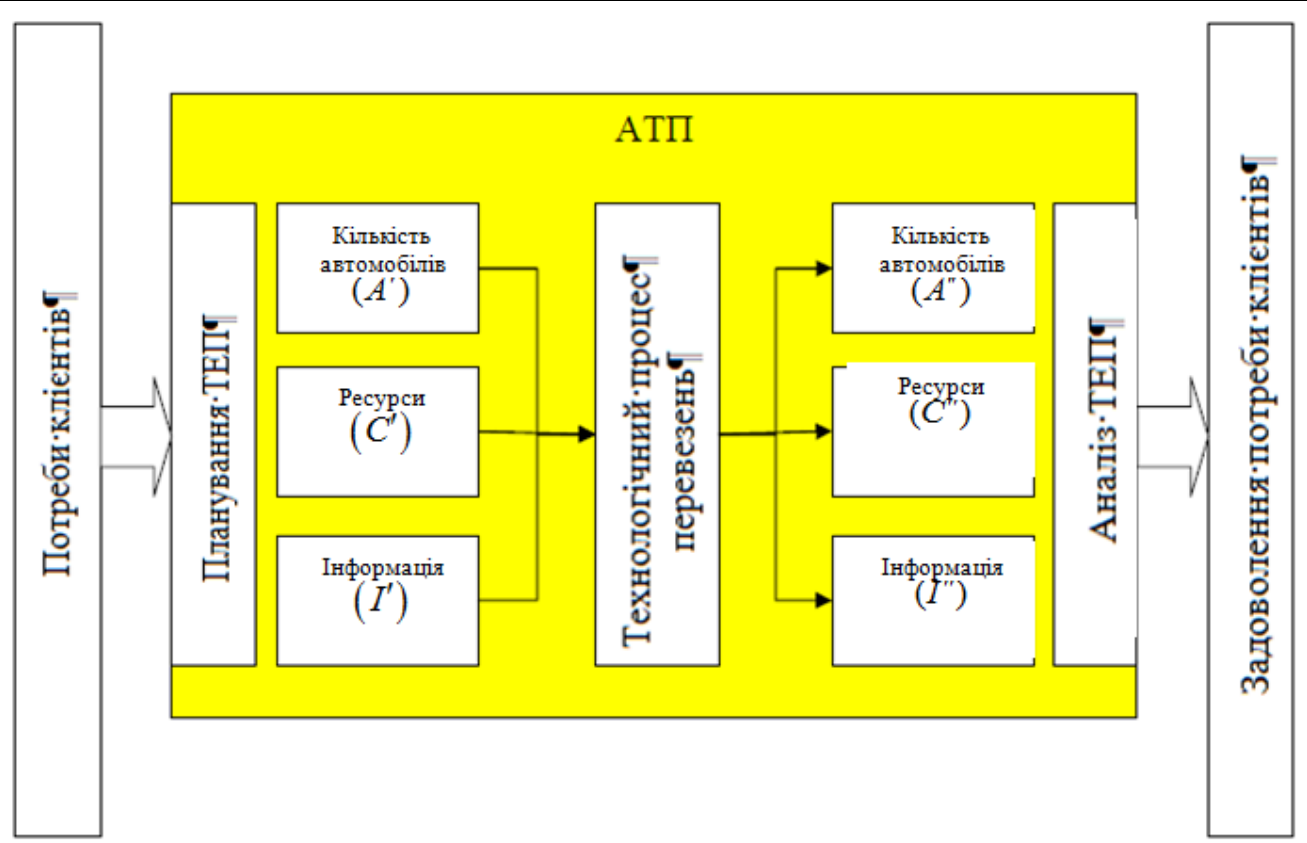

Рисунок 2 - Схема перетворення потреби клієнтів в задоволеність при проходженні через систему автотранспортного підприємства

Під вимогою (заявкою) будемо розуміти потребу у виконанні доставки вантажу.

Час заявки (терміновість її виконання), відстань перевезення (довжина маршруту), тривалість перевезення впливають на величину пропускної здатності системи, оскільки є складовими вхідного потоку вимог. На величину пропускної здатності системи також впливають і внутрішні чинники цієї системи, такі як організація роботи відділів системи, технологічний процес, виробничі потужності підприємства, наявні на конкретний момент часу (за кількістю і станом). При дослідженні системи необхідно враховувати вплив окремих підсистем на роботу всієї системи. Система може успішно справлятися 3 покладеними на неї завданнями тільки за умови, що пропускна здатність системи перевищує сумарний вхідний потік вимог [8] на всі види перевезень. Зайва кількість автомобілів пов'язана 3 великими капітальними вкладеннями, що призводить до заморожування коштів підприємства, тому необхідно точно визначати найбільш вигідну (оптимальну) величину резерву автомобілів. Оптимальна величина резерву виробничих потужностей системи може бути виявлена за економічним критерієм - забезпечення мінімуму витрат або максимуму прибутку [8]. В сучасних умовах функціонування транспортних компаній залишається актуальною задача точного визначення виробітку рухомого складу і ресурсів, необхідних для здійснення доставки вантажів. Одним 3 напрямків раціонального використання ресурсів на автомобільному транспорті є оптимізація витрат методами математичного програмування, за допомогою яких можливо проектування матеріальнотехнічної бази i оптимальних маршрутів доставки вантажів, розподіл рухомого складу i навантажувально-розвантажувальних засобів і багато іншого.

Підсумовуючи вище сказане можна стверджувати, що є необхідність розробки методики оперативного планування (МОП) роботи автомобілів на міжміських маршрутах, що дозволила б:

- одночасно виконувати комплекс операцій з планування роботи автомобілів 3 мінімальними затратами;

- комплексно і точно планувати роботу автомобілів;

- автоматизувати процес розподілу автомобілів за заявками;

- оперативно проводити аналіз роботи рухомого складу на міжміських маршрутах.

При розробці методики в основу покладено фіксацію тимчасового інтервалу «час виконання j-ої заявки» i моментів початку i закінчення виконання роботи ідентифікованого автомобіля в операторі обліку часу.

При автоматизованому обліку в методиці таких факторів, як обсяг вантажу, заявленого до перевезення, час заявки, час обороту рухомого складу на маршруті, зайнятість автомобілів на інших заявках, продуктивність рухомого складу на заявці, розподіл автомобілів по заявках відбувається 3 високою оперативністю, точністю, ефективністю і з меншими затратами.

У методиці враховується специфічна особливість міжміських перевезень виявлена при 
виконанні роботи: велика протяжність маршрутів, що призводить до необхідності віддавати перевагу при виборі рухомого складу автомобілям більшої вантажопідйомності для виконання заявки меншою кількістю оборотів. Цей фактор був врахований в алгоритмі розподілу рухомого складу по заявках на міжміських маршрутах.

Методика дозволяє поєднувати в собі і виконувати одночасно операції по визначенню раціональної вантажопідйомності автомобілів щодо вимог заявки, розрахунку необхідної кількості автомобілів з урахуванням оптимальної продуктивності рухомого складу і витрат на перевезення, обліку витрат на перевезення і розрахунку техніко-експлуатаційних показників роботи рухомого складу, визначення зайнятості парку автомобілів в будь-який момент часу.

Для здійснення оперативного планування за наведеним алгоритмом необхідно сформувати бази даних (БД) вихідної інформації « $3_{j} »$ (отримані заявки), « $A_{i k}$ власн» (власний парк автомобілів), « $A_{i k}$ зал» (залучений парк автомобілів) і бази даних результуючої інформації «ТЕПј» (ТЕП за заявкою),

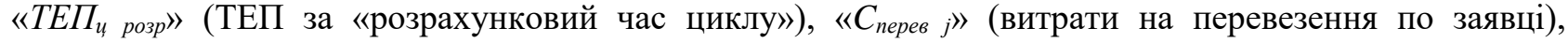

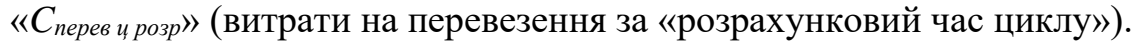

Планування може виконуватися автотранспортним або експедиційним підприємством, що експлуатує власний або залучений вантажний автомобільний транспорт. У автотранспортне або експедиційне підприємство надходять заявки $3_{j}(j-$ порядковий номер заявки, $j=1 \ldots m)$. Вхідний потік вимог складається з:

- найменування і властивостей вантажу;

- обсягу вантажу, заявленого до перевезення $Q_{j}, \mathrm{~T}, j=1 \ldots m$;

- дати поставки $t_{j \text { кін }}$ і терміну заявки $T_{\text {здн }}$, днів, $j=1 \ldots m$;

- пунктів навантаження і розвантаження та виходячи з цього довжини маршруту $l_{m}$, км, $j=1 \ldots m$.

Для здійснення оперативного планування будуть потрібні вихідні дані, представлені на рисунках 3 i 4.



Рисунок 3 - Вихідні дані по заявках для здійснення оперативного планування 




Рисунок 4 - Вихідні дані по автомобілях для здійснення оперативного планування

Розглянемо найбільш складний випадок застосування даної методики.

Автотранспортне підприємство має власні автомобілі $A_{i k}(i$ - типи автомобілів, $i=1 \ldots n$, $k$ - номер автомобіля, $k=1 \ldots p)$ з номінальною вантажопідйомністю $q_{н i}$.

При надходженні заявки із зазначенням виду вантажу і габаритних характеристик автоматично буде задіяний підрозділ БД « $A_{i k}$ власн» або « $A_{i k}$ зал» 3 тим типом рухомого складу, який використовується для перевезення даної категорії вантажів.

Для забезпечення максимально ефективного використання вантажопідйомності автомобіля $\mathrm{i}$ об'єму кузова розраховується коефіцієнт використання вантажопідйомності і вантажомісткості. За допомогою оператора «OR» визначається оптимальне розташування вантажу в кузові автомобіля. При визначенні максимального завантаження транспортних засобів можна використовувати відомі залежності [3]:

$$
\begin{aligned}
& N_{\text {Д }}=\left[Д_{K} /\left(Д_{B} O R W_{B} O R B_{B}\right)\right] \\
& N_{U}=\left[U_{K} /\left(Д_{B} O R W_{B} O R B_{B}\right)\right] \\
& N_{B}=\left[B_{K} /\left(Д_{B} O R U_{B} O R B_{B}\right)\right]
\end{aligned}
$$


$\mathrm{N}_{ш}$ - кількість розташованих одиниць вантажу по ширині кузова транспортного засобу, од.;

$\mathrm{N}_{\mathrm{B}}$ - кількість розташованих одиниць вантажу по висоті кузова транспортного засобу, од.; Дк - довжина кузова транспортного засобу, м;

ШК - ширина кузова транспортного засобу, м;

$\mathrm{B}_{\mathrm{K}}$ - висота кузова транспортного засобу, м;

Дв - довжина вантажу;

Ш $_{\mathrm{B}}$ - ширина вантажу;

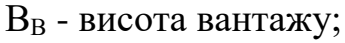

[...] - мінімальне ціле число;

$O R$ - оператор вибору альтернатив «або».

При здійсненні розрахунків слід керуватися обмеженнями, що випливають 3 властивостей вантажу, що перевозиться (максимальна висота укладання, орієнтація і т.д.).

Максимально можливу кількість одиниць вантажу, що розміщується в кузові транспортного 
засобу [3]:

$$
N_{\max }=N_{\text {Д }} \cdot N_{U} \cdot N_{B} \cdot
$$

Коефіцієнти використання вантажопідйомності і вантажомісткості визначаються за класичними формулами.

Для визначення оптимального маршруту і пробігу рухомого складу можна застосовувати існуючі програмні продукти, в тому числі зазначені в таблиці 1.

Таблиця 1 - Характеристики сучасних програмних продуктів 3 планування перевезень

\begin{tabular}{|c|c|c|c|c|c|c|c|c|c|c|c|}
\hline $\begin{array}{c}\text { Постачальник: } \\
\text { назва IT рішення }\end{array}$ &  & 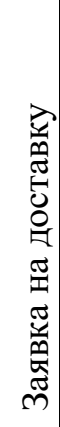 & 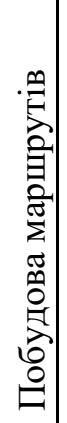 & 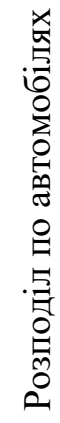 & 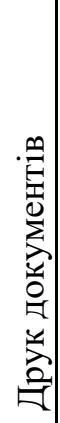 & 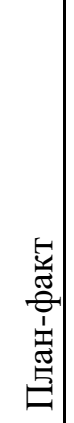 & 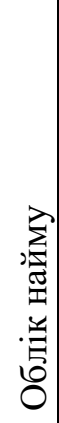 & 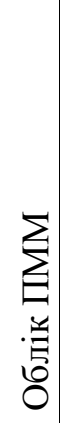 & 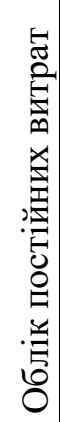 & 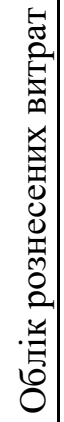 & 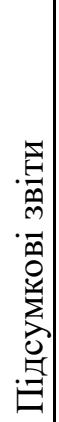 \\
\hline $\begin{array}{c}\text { ДТКсофт: IAC } \\
\text { "Вантажоперевезення }\end{array}$ & & & & & & & & & & & \\
\hline $\begin{array}{c}\text { РАРУС: Управління } \\
\text { транспортом }\end{array}$ & & & & & & & & & & & \\
\hline ФОРЕС: Автотранспорт & & & & & & & & & & & \\
\hline $\begin{array}{c}\text { Акселот: Управління } \\
\text { перевезеннями }\end{array}$ & & & & & & & & & & & \\
\hline 1ТОВ: Центр логістики & & & & & & & & & & & \\
\hline AHTOP: Logistics Master & & & & & & & & & & & \\
\hline ESRI: АгсLogistics Route & & & & & & & & & & & \\
\hline ТопПлан: TopLogistics & & & & & & & & & & & \\
\hline СДС: ОПТИМУМ ГИС & & & & & & & & & & & \\
\hline Эрмасофт: СИТИ-Доставка & & & & & & & & & & & \\
\hline
\end{tabular}

Для вирішення поставленої в роботі мети введемо поняття «Ідентифікований автомобіль» і «оператор обліку часу зайнятості ідентифікованого автомобіля».

Ідентифікуємо рухомий склад, використовуємо для цього додатковий індекс «k» $(k-$ номер автомобіля, що дозволяє його ідентифікувати, $\mathrm{k}=1 \ldots \mathrm{p}$ ), що дозволить 3 більшою точністю $\mathrm{i}$ оперативністю здійснювати вибір рухомого складу серед вільних автомобілів для роботи на $j$-ій заявці.

Застосовуємо оператор обліку часу (OOЧ), який дозволяє фіксувати:

- часовий інтервал «час виконання $j$-ої заявки»;

- моменти початку і закінчення виконання роботи ідентифікованого транспортного засобу;

- часовий інтервал «зайнятість автомобіля $i$-го типу $k$-го номера на $j$-ій заявці». Це дозволяє врахувати і впорядкувати в часі надійшовші на автотранспортне або експедиційне підприємство заявки і уникнути надалі трудомісткої побудови графіка випуску автомобілів вручну.

Блок-схема $М O П$ роботи автомобілів на міжміських маршрутах представлена на рисунку 5.

Розподіл рухомого складу по заявках проводиться у відповідності до алгоритму, представленого на рисунку 6. 


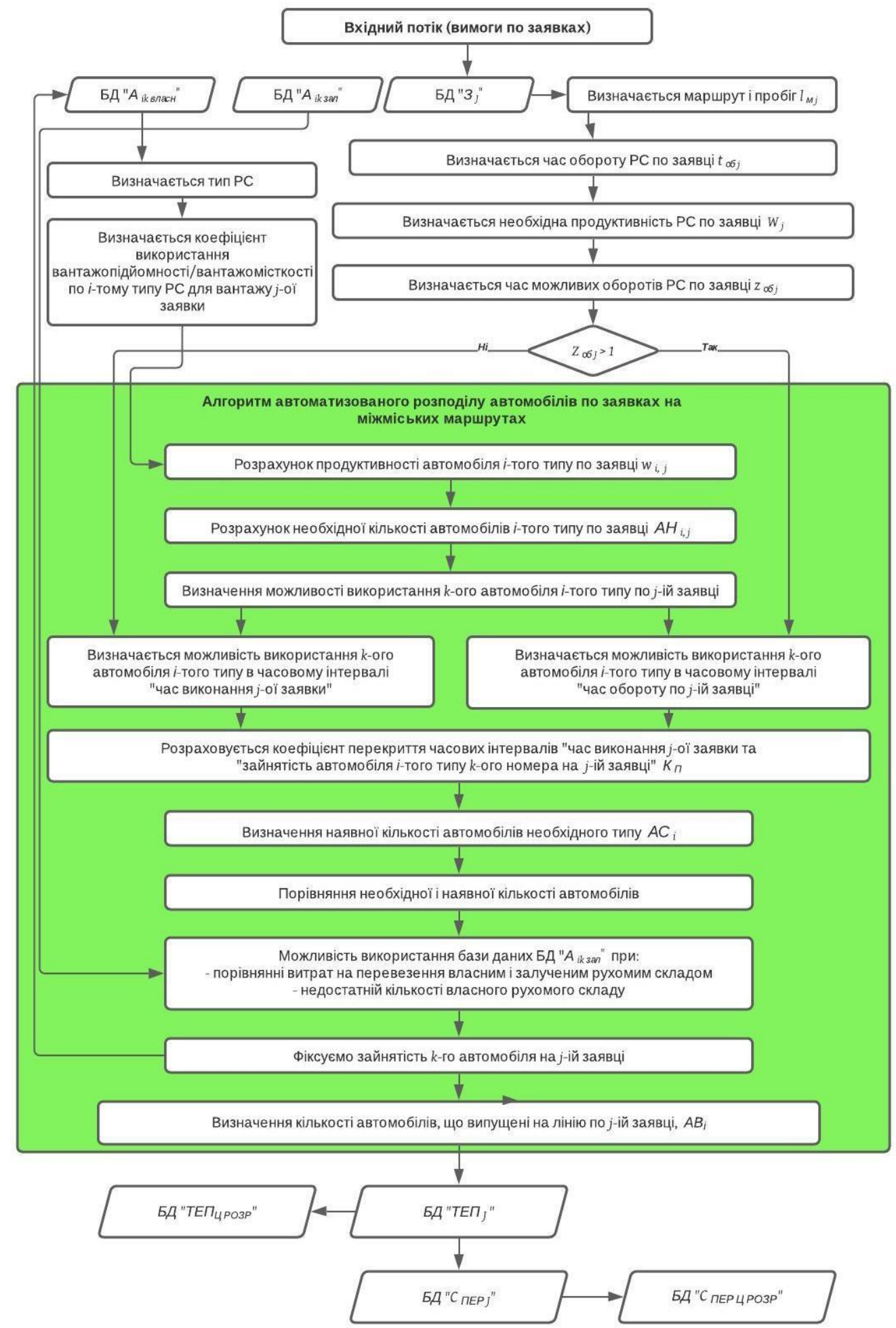

Рисунок 5 - Блок-схема методики оперативного планування роботи автомобілів на міжміських маршрутах

Важливим елементом методики оперативного планування роботи автомобілів на міжміських маршрутах $\epsilon$ алгоритм автоматизованого розподілу автомобілів по заявках на міжміських маршрутах 3 використанням оператора обліку часу і коефіцієнта перекриття тимчасових інтервалів «час заявки» $\mathrm{i}$ «зайнятість автомобіля».

При надходженні чергової заявки розраховується:

- термін виконання заявки в годинах $T_{\text {згод }}$, год, $\mathrm{j}=1 \ldots m$;

- час обороту автомобіля на $j$-ій заявці $t_{о б} j$, год;

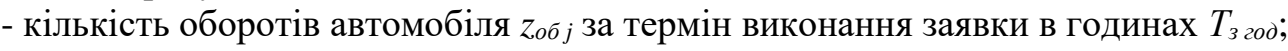


- необхідна продуктивність рухомого складу по заявці:

$$
W_{j}=\frac{Q_{j}}{t_{\text {об } j}},(1)
$$

де $W_{j}$ - потрібна продуктивність рухомого складу за заявкою, т/год;

$Q_{j}$ - обсяг вантажу, заявленого до перевезення, т;

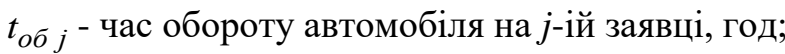

$W_{i j}$ - продуктивність $i$-го типу автомобіля на $j$-ій заявці:

$$
W_{i j}=\frac{q_{H i} \cdot \gamma}{t_{\text {бб } j}},(2)
$$

де $W_{i j}$ - продуктивність $i$-го типу автомобіля на $j$-ій заявці, т/год;

$q_{н i}$ - номінальна вантажопідйомність автомобіля i-го типу, т;

$\gamma$ - коефіцієнт використання вантажопідйомності і вантажомісткості (з допомогою оператора «OR» визначається оптимальне розташування вантажу в кузові автомобіля);

$t_{\text {об } j}$ - час обороту автомобіля на $j$-ій заявці, год.

Вибір оптимальної продуктивності рухомого складу на заявку здійснюється серед наявних вільних автомобілів, враховуючи умову:

$$
\sum_{i=1}^{n} \sum_{j=1}^{m} W_{i j}=W_{j} .
$$

При виборі автомобіля враховуються властивості вантажу і спеціалізація рухомого складу. Для розрахунку використовується підрозділ бази даних « $A_{i k}$ власн» або « $A_{i k}$ зал» по певній групі рухомого складу (бортові, рефрижератори, самоскиди, цистерни).

Вибір рухомого складу починаємо з розрахунку необхідної кількості автомобілів максимальної продуктивності $w_{i=1, j}\left(w_{i=1, j}=\max w_{i, j}\right)$ :

$$
A H_{i, j}=\frac{W_{j}-\sum_{i=1}^{n-1} A B_{i} w_{i j}}{w_{i j}},(3)
$$

де $A H_{i, j}$ - необхідна кількість автомобілів $i$-го типу на $j$-ій заявці, 3 максимальною продуктивністю, од.;

$A B_{i}$ - автомобілі $i$-го типу, вибрані для роботи на $j$-ій заявці, од.;

$w_{i j}$ - максимальна продуктивність рухомого складу на $j$-ій заявці із наявного на підприємстві, т/год.

Визначається можливість використання автомобіля $i=1$ типу $k$-го номера для роботи на $j$-ій заявці (чи вільний даний автомобіль на часовому інтервалі «час виконання $j$-ої заявки») 3 використанням $O O Ч$ та БД « $A_{i k}$ власн». Для цього розраховується коефіцієнт перекриття $K_{\Pi \text { : }}$ :

$$
K_{\Pi}=\frac{t_{A_{i k m n о u}}}{t_{A_{i k(m-1) \text { кiнu }}}} \text {,(4) }
$$

де $K_{\Pi}$ - коефіцієнт перекриття тимчасових інтервалів «час виконання $j$-ої заявки» і « зайнятість автомобіля $i$-го типу $k$-го номера на $j$-ій заявці»;

$t_{A_{i k m n о ч}}$ - точка початку роботи автомобіля $i$-го типу $k$-го номера $A_{i k}$ на запланованій $j$-ій заявці, год; 
$t_{A_{i k(m-1) \kappa i н и}}$ - точка закінчення роботи автомобіля $i$-го типу $k$-го номера $A_{i k}$ на попередній заявці,год.

Використовуємо оператор « $K_{\Pi} \geq 1 »$. Якщо $K_{\Pi} \geq 1$, то цей автомобіль може бути задіяний на планованій заявці і присвоюємо йому «1»-допущений. Визначаємо кількість автомобілів $i=1$ типу вільних для виконання даної заявки і позначаємо його $A C_{i}$. При виборі автомобіля можна встановити пріоритет для тих автомобілів, які мають найбільше значення $K_{\Pi \text {. }}$ Це забезпечить рівномірне використання автомобілів.

Якщо $K_{\Pi}<1$, то цей автомобіль не може бути задіяний на планованій заявці, тому блокуємо його, привласнюючи йому «0» - не допущений.

У тому випадку, якщо за «час виконання $j$-ої заявки» може бути виконано кілька оборотів на маршруті, то розбиваємо цей часовий інтервал на відрізки «час одного обороту на $j$-ій заявці» $\mathrm{i}$ визначаємо можливість використання автомобілів на кожному з цих відрізків за формулою (4).

Наведений вище оператор в програмній оболонці представлений як оператор порівняння тимчасового інтервалу «час виконання $j$-ої заявки» і тимчасових інтервалів «зайнятість автомобіля $i$ го типу $k$-го номера на $j$-ій заявці».

Порівнюємо отримане раніше значення необхідної кількості автомобілів $i=1$ типу $A H_{i=1, j} 3$ наявною кількістю власних вільних для виконання даної заявки автомобілів $A C_{i}$.

Використовуємо оператор « $A H_{i=1, j} \leq A C_{i=1, j}$ » і додатковий оператор « $A C_{i=1, j}<1 »$.

Якщо автомобілів потрібно менше одиниці, а вільних автомобілів $i=1$ типу немає (ситуація №1), то зробимо розрахунок необхідної кількості автомобілів з найбільшим наступним значенням $w_{i j}$, а саме $w_{i=2, j}$ за формулою (3) і будемо слідувати наведеному раніше алгоритму.

Якщо автомобілів потрібно більше одиниці, а вільних автомобілів недостатньо (ситуащія №2), то приймаємо для роботи на $j$-ій заявці кількість автомобілів $i$-го типу рівне наявним $A C_{i j}$ :

$$
A B_{i}=A C_{i j},(5)
$$

при цьому:

- враховується пріоритет на виконання j-ої заявки, його мають автомобілі 3 найбільшим позитивним значенням $K_{\Pi \text {; }}$;

- присвоюється обраним для роботи на даній $j$-ій заявці автомобілів $i$-го типу і $k$-го номера «зайнятість автомобіля $i$-го типу $k$-го номера на $j$-ій заявці» в БД « $A_{i k}$ власн» для того щоб використовувати цю інформацію при обробці наступних заявок.

Може скластися ситуація, коли власних автомобілів недостатньо для виконання обсягу



Якщо $A H_{i j} \leq A C_{i j}$ i $A H_{i j} \leq 1$, це означає, що необхідних автомобілів потрібно менше одиниці і вільних автомобілів $i=1$ типу досить (ситуащчія №3).

Якщо $A H_{i j} \leq 1$, то в цьому випадку необхідно буде порівняти декілька альтернативних варіантів за витратами на перевезення:

Варіант 1. Приймаємо для роботи на $j$-ій заявці один автомобіль $i$-го типу:

$$
A B_{i}=\text { ceiling } A H_{i j}=1=A C_{i j},(6)
$$

при цьому враховується пріоритет автомобілів на виконання $j$-ої заявки, і обраним для роботи на даній заявці автомобілям присвоюється «зайнятість автомобіля $i$-го типу $k$-го номера на $j$-ій

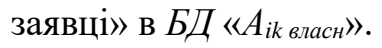

Розраховуємо витрати на перевезення по $j$-ій заявці при використанні цього автомобіля $i$-го типу, використовуємо при цьому:



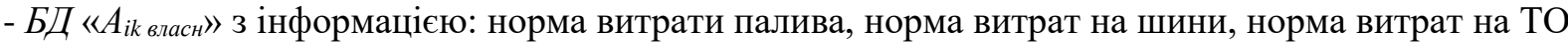
i ТР, норма амортизаційних відрахувань по рухомому складу, вартість автомобіля $i$-го типу;

- відомі формули для розрахунку експлуатаційних витрат.

Варіант 2. Розглянемо рухомий склад меншої вантажопідйомності і продуктивності. Зробимо розрахунок необхідної кількості автомобілів з найбільшим наступним значенням $w_{i j}$, а саме $w_{i=2, j}$ за 
формулою аналогічною (3):

$$
A H_{i=2, j}=\frac{W_{j}-\sum_{i=1}^{n-1} A B_{i k} w_{i j}}{w_{i=2, j}}
$$

слідуючи викладеному раніше алгоритму, неодмінно перевіряючи наявність вільних автомобілів.

Якщо і тут $A H_{i j}<1$, то підемо аналогічно діям при варіанті 1.

Якщо $A H_{i j}=1$, то без додаткових розрахунків і порівнянь приймаємо для роботи на даній $j$-ій заявці саме цей автомобіль $i$-го типу $k$-го номера, відзначаємо «зайнятість автомобіля $i$-го типу $k$-го номера на $j$-ій заявці» в БД « $A_{i k}$ власн $»$ і завершуємо розрахунки.

Якщо $A H_{i j}>1$, то при наявності вільних автомобілів приймаємо для роботи на $j$-ій заявці автомобілі $i$-го типу в кількості необхідних з заокругленням у більшу сторону

$$
A B_{i}=\text { ceiling } A H_{i j},(7)
$$

і розраховуємо витрати на перевезення по $j$-ій заявці при використанні автомобілів цього $i$-го типу, використовуємо при цьому БД «3ز», БД « $A_{i k}$ власн» і відомі формули для розрахунку експлуатаційних витрат.

Як зазначалося вище порівнюємо ці альтернативні варіанти по витратах на перевезення і вибираємо той варіант, якому відповідають найменші витрати і завершуємо розрахунки.

Тепер розглянемо ситуацію №4, їй відповідає відповідь «ні» при використанні додаткового оператора « $A H_{i j}<1 »$. Це означає, що $A H_{i j}>1$ i вільних автомобілів $i=1$ типу досить. В цьому випадку необхідно буде порівняти декілька альтернативних варіантів по витратах на перевезення:

Варіант 1. Приймаємо для роботи на $j$-ій заявці автомобілі $i$-го типу в кількості потрібних 3 заокругленням у більшу сторону (7):

$$
A B_{i}=\text { ceiling } A H_{i j}
$$

При цьому врахуємо пріоритет автомобілів на виконання $j$-ої заявки $\mathrm{i}$ дамо обраним автомобілям «зайнятість автомобіля $i$-го типу $k$-го номера на $j$-ій заявці » в БД « $A_{i k}$ власн».

Розраховуємо витрати на перевезення по $j$-ій заявці при використанні автомобілів цього $i$-го типу.

Варіант 2. Приймаємо для роботи на $j$-ій заявці автомобілі $i$-го типу в кількості потрібних 3 заокругленням в меншу сторону:

$$
A B_{i}=\operatorname{int} A H_{i j} .(8)
$$

При цьому врахуємо пріоритет автомобілів на виконання $j$-ої заявки і присвоїмо обраним автомобілям «зайнятість автомобіля $i$-го типу $k$-го номера на $j$-ій заявці » в БД « $A_{i k}$ власн».

Зробимо розрахунок необхідної кількості автомобілів з найбільшим наступним значенням $w_{i j}$, а саме $w_{i=2, j}$ за формулою аналогічною (3)

$$
A H_{i=2, j}=\frac{W_{j}-\sum_{i=1}^{n-1} A B_{i k} w_{i j}}{w_{i=2, j}} .
$$

слідуючи викладеному раніше алгоритму, неодмінно перевіряючи наявність вільних автомобілів. Розраховуємо витрати на перевезення для варіанту 2.

Порівнюємо ці альтернативні варіанти за витратами на перевезення і вибираємо той варіант, якому відповідають найменші витрати та завершуємо розрахунки.

Після того, як фіксується результат $A B_{i}$, розраховується величина $\Delta W_{j}$ яка показує залишок нерозподіленого по автомобілях вантажу:

$$
\Delta W_{j}=W_{j}-\sum_{i=1}^{n-1} A B_{i} w_{i j} \cdot(9)
$$


Якщо $\Delta W_{j} \leq 0$, то розрахунки закінчені, якщо $\Delta W_{j}>0$, то продовжуємо перебір рухомого складу за індексами «k» $\mathrm{i} « i »$.

Блок-схема алгоритму представлена на рисунку 6.

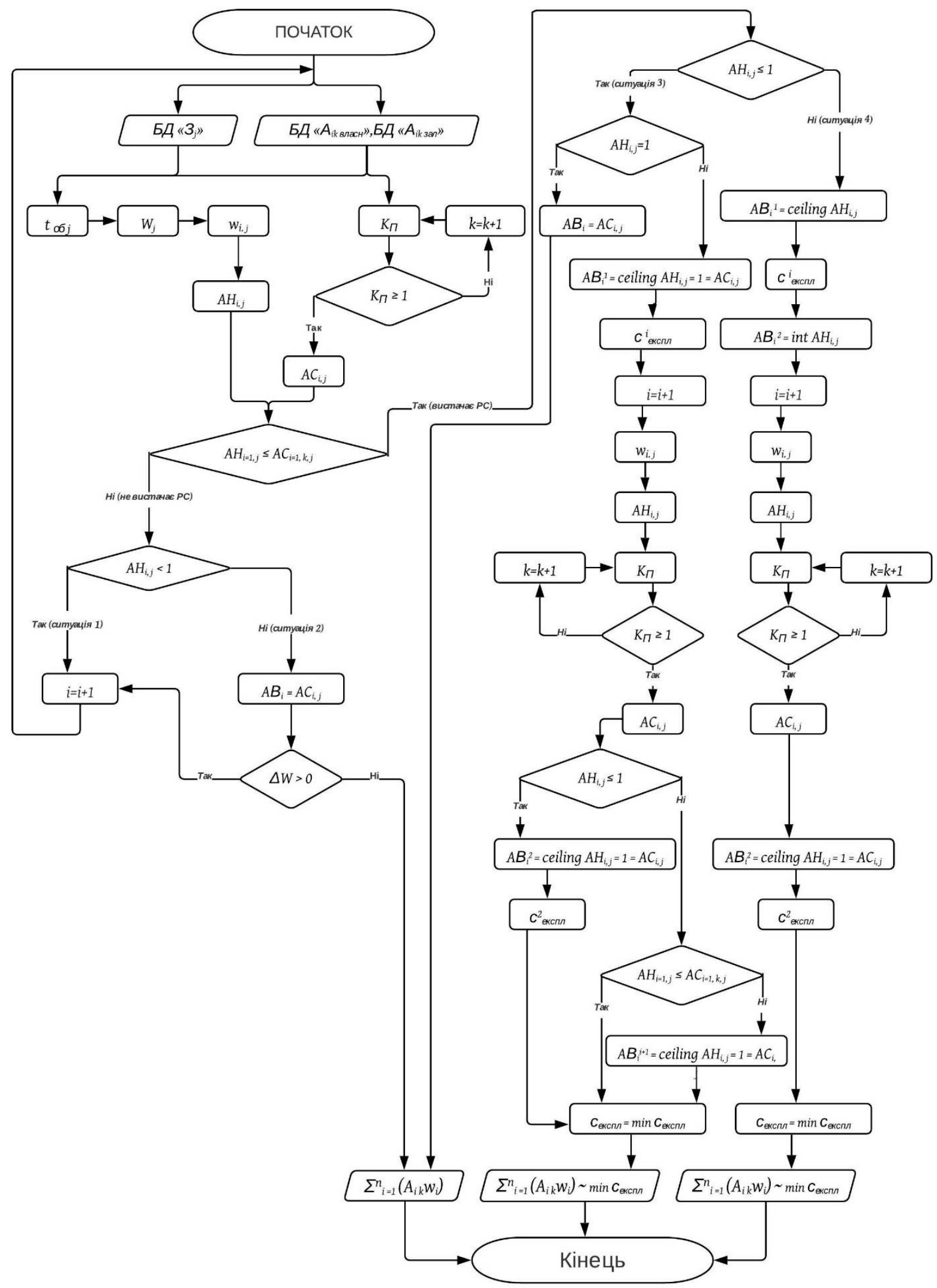

Рисунок 6 - Алгоритм автоматизованого розподілу автомобілів за заявками на міжміських маршрутах 


\section{ОБГОВОРЕННЯ РЕЗУЛЬТАТІВ ДОСЛІДЖЕНЬ}

На сьогоднішній день існує безліч методик для оптимізації роботи рухомого складу і визначення ТЕП його роботи. Однак більшою частиною, вони можуть бути застосовані для здійснення планування і оцінки роботи автомобілів, зайнятих на міських маршрутах.

Методики, які працюють сьогодні, присвячені окремим завданням, таким як визначення оптимальної вантажопідйомності парку рухомого складу, розрахунок техніко експлуатаційних показників, в тому числі необхідної кількості автомобілів, розподіл рухомого складу за заявками із застосуванням методів лінійного програмування, складання графіка роботи автомобілів, розрахунок витрат на перевезення та інші.

Розроблена методика оперативного планування роботи автомобілів на міжміських маршрутах дозволить усунути недоліки існуючих і оперативно виконувати планування роботи автомобілів на міжміських маршрутах.

\section{ВИСНОВОК}

Розроблена методика оперативного планування роботи автомобілів на міжміських маршрутах враховує специфічні особливість міжміських перевезень та дозволяє поєднувати в собі і виконувати одночасно операції по визначенню раціональної вантажопідйомності автомобілів щодо вимог заявки, розраховувати необхідну кількість автомобілів з урахуванням оптимальної продуктивності рухомого складу і витрат на перевезення, обліковувати витрати на перевезення i розраховувати технікоексплуатаційні показники роботи рухомого складу, визначати зайнятість парку автомобілів в будьякий момент часу.

\section{ПЕРЕЛІК ДЖЕРЕЛ ПОСИЛАННЯ}

1. Смрковская В.Ю. Структура и параметры систем доставки грузов: [зб. наук. праць // Методи та засоби управління розвитком транспортних систем]. - Одеса: ОНМУ, 2005. - № 10. - С. 173-184.

2. Менухова Т.А. Совершенствование системы планирования автотранспортного предприятия в целях повышения его конкурентоспособности // Социально-гуманитарный вестник Юга России. Научный журнал. №2 (33), 2013.

3. Основы транспортно-экспедиционного обслуживания: учебно- методический комплекс / сост. Т.К. Екшикеев, А.В. Терентьев, В.И. Костенко, Н.С. Нестеркина. - СПб.: Изд-во СЗТУ, 2008.

4. Прокудін Г.С. Моделювання взаємодії автомобільних транспортних підприємств на міжміських перевезеннях вантажів / Г.С. Прокудін, С.М. Шарай, М.С.Оліскевич, М.В. Рой // Вісник машинобудування та транспорту. Науковий журнал. - Вінниця: ВНТУ, 2019. - №2 (10). С. 95-101.

5. Калініченко О.П. Оптимізація рішення задач оперативного планування вантажних перевезень на автомобільному транспорті / О.П. Калініченко, О.В. Павленко, В.М. Нефьодов // Комунальне господарство міст. Збірник наукових праць. - Х.: ХНАМГ, 2018. - Випуск 142. С. 108-113.

6. Оліскевич М.С. Оптимізація транспортних циклів залежно від обсягу прогнозованих вантажопотоків / М.С. Оліскевич // Вісник Східноукраїнського національного університету ім. В. Даля. Науковий журнал. - Луганськ: СНУ, 2013. - № 5 (194). С. 140-145.

7. Подоляк О.С., Крамаренко Ю.М. Оптимізація оперативного планування міжміських автомобільних вантажних перевезень / О.С. Подоляк, Ю.М. Крамаренко // Машинобудування. Збірник наукових праць. - Х.: УІПА, 2018. - №21. С. 169-173.

8. Житков, В.А. Методы оперативного планирования грузовых автомобильных перевозок [Текст] / В.А. Житков, К.В. Ким - М.: Транспорт, 1982. - 184с.

9. Войтенков, С.С. Совершенствование оперативного планирования перевозок грузов помашинными отправками в городах [Текст]: автореферат дис. кандидата тех-нических наук : 05.22.10 / Сергей Сергеевич Войтенков - Иркутск, 2011. - 19 с.

\section{REFERENCES}

1. Smrkovskaia V.Iu. (2005). Struktura i parametry sistem dostavki gruzov [Structure and parameters of cargo delivery systems]. Zbirnyk naukovykh prats // Metody ta zasoby upravlinnia rozvytkom transportnykh system - Collection of scientific works // Methods and means of managing the development of transport systems, 10, 173-184 [in Ukrainian].

2. Menuhova T.A. (2013). Sovershenstvovanie sistemy planirovanija avtotransportnogo predprijatija v celjah povyshenija ego konkurentosposobnosti [Improving the planning system of a motor transport enterprise in order to increase its competitiveness]. Social'no-gumanitarnyj vestnik Juga Rossii. Nauchnyj 
zhurnal - Social and Humanitarian Bulletin of the South of Russia. Science Magazine, 2 (33) [in Russian].

3. Ekshikeev, T.K., \& Terent'ev, A.V., \& Kostenko, V.I., \& Nesterkina, N.S. (2008). Osnovy transportno-ekspedicionnogo obsluzhivanija [Fundamentals of freight forwarding services]. Saint Petersburg: SZTU [in Russian].

4. Prokudin, H.S., \& Sharai, S.M., \& Oliskevych, M.S., \& Roi, M.V. (2019). Modeliuvannia vzaiemodii avtomobilnykh transportnykh pidpryiemstv na mizhmiskykh perevezenniakh vantazhiv [Modeling of interaction of automobile transport enterprises on long-distance freight transportation]. Visnyk mashynobuduvannia ta transportu. Naukovyi zhurnal - Bulletin of Mechanical Engineering and Transport. Scientific journal, 2 (10), 95-101 [in Ukrainian].

5. Kalinichenko, O.P., \& Pavlenko, O.V., \& Nefodov, V.M. (2018). Optymizatsiia rishennia zadach operatyvnoho planuvannia vantazhnykh perevezen na avtomobilnomu transporti [Optimization of the decision of problems of operative planning of freight transportations on motor transport]. Komunalne hospodarstvo mist. Zbirnyk naukovykh prats - Municipal utilities. Collection of scientific works, 142, 108-113 [in Ukrainian].

6. Oliskevych M.S. (2013). Optymizatsiia transportnykh tsykliv zalezhno vid obsiahu prohnozovanykh vantazhopotokiv [Optimization of transport cycles depending on the volume of forecasted cargo flows]. Visnyk Skhidnoukrainskoho natsionalnoho universytetu im. V. Dalia. Naukovyi zhurnal - Bulletin of the East Ukrainian National University. V. Dahl. Scientific journal, 5 (194), 140-145 [in Ukrainian].

7. Podoliak, O.S., \& Kramarenko, Yu.M. (2018). Optymizatsiia operatyvnoho planuvannia mizhmiskykh avtomobilnykh vantazhnykh perevezen [Optimization of operational planning of long-distance automobile freight transportation]. Mashynobuduvannia. Zbirnyk naukovykh prats - Mechanical Engineering. Collection of scientific works, 21, 169-173 [in Ukrainian].

8. Zhitkov, V.A., \& Kim, K.V. (1982). Metody operativnogo planirovanija gruzovyh avtomobil'nyh perevozok [Methods of operational planning of freight road transport]. Moscow: Transport [in Russian].

9. Vojtenkov, S. S. (2011). Sovershenstvovanie operativnogo planirovanija perevozok gruzov pomashinnymi otpravkami $\mathrm{v}$ gorodah [Improving the operational planning of cargo transportation by car dispatches in cities]. Ph.D. thesis. Irkutsk [in Russian].

\section{Handziuk, D. Handziuk, B. Shumik. Development of methods of operational planning of vehicles on long city routes}

Currently, the successful operation of all sectors of the economy is impossible without efficient transport services. The organization of transport should ensure the efficient supply of industrial production, agriculture, other sectors of the economy, as well as meet the needs of the population in transportation from a systemic standpoint. An integrated approach to the organization and planning of transportation requires the achievement of minimum costs both in the entire transport service system and in its individual elements. The solution of this problem is impossible without replacing the existing technologies and methods of organization and planning of the transport process with modern ones.

Modern requirements for the organization of the transportation process and the quality of transportation performed by road dictate the need for new organizational and technological solutions in transportation planning using program-targeted and logistical principles.

The existing organization of the operational planning system does not always meet the real needs of participants in the process of road freight. The main disadvantage today is that the methodological framework is segmented and describes the individual stages of planning the transportation process. The methods working today are devoted to certain tasks, such as determining the optimal load capacity of the rolling stock, calculation of technical and operational indicators, including the required number of cars, distribution of rolling stock on request using linear programming methods, scheduling of cars, calculation of costs for transportation and others.

Execution of such a variety of disparate operations and tasks in modern conditions without a comprehensive approach to their solution, as well as without automation of processing significant amounts of information is inefficient.

In addition, the methods of calculating the required number of cars have serious errors, this is expressed in the discrepancy between the calculated and actual values.

Despite the fact that in recent years there has been an active development and implementation of automated document management and vehicle planning programs for motor transport enterprises, currently there is no methodology that provides comprehensive planning and solution of the above tasks taking into account the specifics of long-distance transportation. motor transport in Ukraine are associated with the intensive development of long-distance road freight transport. 
Key words: transportation, technical and operational indicators, long-distance route, system, operational planning, application, methodology, algorithm, automation, methodological base.

ГАНДЗЮК Микола Олександрович, кандидат технічних наук, доцент кафедри автомобілів і транспортних технологій Луцького національного технічного університету, e-mail: Gandzyuk64.MG@ gmail.com. http://orcid.org/0000-0002-3552-4256.

ГАНДЗЮК Дмитро Миколайович, магістр із спеціальності «Автомобілі і автомобільне господарство», e-mail: Gandzyukd@gmail.com.

ШУМІК Богдан Володимирович, інженер-конструктор ДП «Автоскладальний завод №1» ПАТ Автомобільна компанія «Богдан Моторс», e-mail: Shymik2798@ gmail.com.

Mykola HANDZIUK, Ph.D in Engeneering, associate professor of automobiles and transport technologies department, Lutsk National Technical University, e-mail: Gandzyuk64.MG@gmail.com. http://orcid.org/0000-0002-3552-4256.

Dmitriy HANDZIUK, Master's degree in "Cars and Automotive Industry", e-mail: Gandzyukd@gmail.com.

Bohdan SHUMIK, design engineer, SE “Auto Assembly Plant №1” PJSC Automobile Company "Bogdan Motors", e-mail: Shymik2798@ gmail.com.

DOI 10.36910/automash.v2i17.634 